\title{
Recharge sources and hydrogeochemical evolution of groundwater in semiarid and karstic environments: A field study in the Granada Basin (Southern Spain)
}

\author{
Claus Kohfahl $^{\mathrm{a}, *}$, Christoph Sprenger ${ }^{\mathrm{a}}$, Jose Benavente Herrera ${ }^{\mathrm{b}}$, \\ Hanno Meyer $^{\mathrm{c}}$, Franzisca Fernández Chacón ${ }^{\mathrm{d}}$, Asaf Pekdeger ${ }^{\mathrm{a}}$

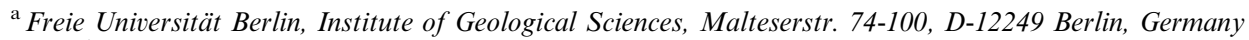 \\ ${ }^{\mathrm{b}}$ Instituto del Agua de la Universidad de Granada, Ramón y Cajal, 4, 18071 Granada, Spain \\ ${ }^{\mathrm{c}}$ Isotope Laboratory of the Alfred Wegener Institute for Polar and Marine Research, Research Unit Potsdam, \\ Telegrafenberg A 43, 14473 Potsdam, Germany \\ d Dpto. Hidrogeología y Aguas Subterráneas, Instituto Geológico y Minero de España, Oficina de Proyectos, \\ Urb. Alcazar del Genil 4, Edificio Zulema bajo, 18006 Granada, Spain
}

Received 25 October 2006; accepted 20 September 2007

Editorial handling by A. Herczeg

Available online 15 January 2008

\begin{abstract}
The objective of this study is to refine the understanding of recharge processes in watersheds representative for karstic semiarid areas by means of stable isotope analysis and hydrogeochemistry. The study focuses on the Granada aquifer system which is located in an intramontane basin bounded by high mountain ranges providing elevation differences of almost $2900 \mathrm{~m}$. These altitude gradients lead to important temperature and precipitation gradients and provide excellent conditions for the application of stable isotopes of water whose composition depends mainly on temperature. Samples of rain, snow, surface water and groundwater were collected at 154 locations for stable isotope studies $\left(\delta^{18} \mathrm{O}, \mathrm{D}\right)$ and, in the case of ground- and surface waters, also for major and minor ion analysis. Thirty-seven springs were sampled between 2 and 5 times from October 2004 to March 2005 along an altitudinal gradient from 552 masl in the Granada basin to 2156 masl in Sierra Nevada. Nine groundwater samples were taken from the discharge of operating wells in the Granada basin which are all located between 540 and 728 masl. The two main rivers were monitored every $2-3$ weeks at three different altitudes. Rainfall being scarce during the sampling period, precipitation could only be sampled during four rainfall events. Calculated recharge altitudes of springs showed that source areas of mainly snowmelt recharge are generally located between 1600 and 2000 masl. The isotope compositions of spring water indicate water sources from the western Mediterranean as well as from the Atlantic without indicating a seasonal trend. The isotope pattern of the Quaternary aquifer reflects the spatial separation of different sources of recharge which occur mainly by bankfiltration of the main rivers. Isotopic signatures in the southeastern part of the aquifer indicate a considerable recharge contribution by subsurface flow discharged from the adjacent carbonate aquifer. No evaporation effects due to agricultural irrigation were detected.
\end{abstract}

(c) 2008 Elsevier Ltd. All rights reserved.

\footnotetext{
* Corresponding author. Fax: +49 3083870742.

E-mail address: kohfahl@zedat.fu-berlin.de (C. Kohfahl).
} 


\section{Introduction}

During the last decades groundwater exploitation in the Mediterranean region has increased dramatically mainly due to an increase in irrigated agriculture, tourism and industry (Vandenschrick et al., 2002). To meet the needs of drinking water for future generations, sustainable watershed management is essential for drinking water supply especially in semiarid areas and requires a more detailed knowledge about recharge processes.

In many cases conventional hydrogeochemical studies are not sufficient to characterise groundwater hydrodynamics or to detect recharge areas and source areas of recharged water. Since the isotopic composition of $\mathrm{O}$ and $\mathrm{H}$ in groundwater does not change as a result of rock-water interactions at low temperatures it provides a helpful means to bridge this knowledge gap (e.g. Sidle, 1998). The application of isotope-based methods has become well established for water resource assessment, development and management in the hydrological sciences, and is now an integral part of many water quality and environmental studies (Clark and Fritz, 1999; Cook and Herczeg, 1999).

Several studies using hydrochemistry and stable isotopes of water have already been realised to characterise recharge processes in similar hydrogeologic environments. Long and Putnam (2004) developed a linear model to describe three components of water flow in karst aquifers using ${ }^{18} \mathrm{O}$ data. Barbieri et al. (2005) characterised groundwater flowpaths and recharge altitudes in a karst aquifer of Central Italy by a combined study of hydrochemistry and stable isotopes $\left({ }^{2} \mathrm{H},{ }^{18} \mathrm{O}\right.$ and $\left.{ }^{87} \mathrm{Sr} /{ }^{86} \mathrm{Sr}\right)$. Marfia et al. (2003) combined the analysis of major and minor ions, $\delta^{13} \mathrm{C}$ and stable isotopes of water to investigate the origin and the hydrogeochemical evolution of the ground- and surface water in a karst dominated geologic setting. Vandenschrick et al. (2002) studied the composition of stable isotopes in the Sierra de Gador (southern Spain) in order to distinguish between Atlantic and western Mediterranean origins of precipitation and its impact on the isotopic signature of surface and groundwater along its pathway from the summits of the Sierra de Gador towards the coastal plain. Cruz-San Julian et al. (1992) monitored D and ${ }^{18} \mathrm{O}$ compositions in several single rain events in south eastern Spain from November 1989 until April 1990. They observed that variations were clearly related to different source regions of the vapour (Atlantic Ocean or
Mediterranean Sea) as well as to different trajectories of precipitating air masses. The range of the $D$-values observed in samples from local springs and wells (between +10 and $+13 \%$ ) indicated that groundwater in the studied areas is recharged predominantly by the Atlantic-derived precipitation.

The objective of this study was the investigation of recharge processes and the hydrogeochemical evolution of groundwater in semiarid basins subjected to increasing agricultural exploitation. The high differences in elevation in the study area provide an excellent possibility to detect recharge areas of groundwater using stable isotopes of water. The authors report the stable isotope ratios of $\mathrm{H}$ and $\mathrm{O}$ and concentrations of major and minor ions of precipitation, surface water and groundwater that are essential in understanding geochemical processes affecting water quality. The results of this study may contribute to the optimisation of water resources management.

\subsection{Site description}

The Granada basin is located in southern Spain, enclosing the town of Granada and forming an intramontane basin within the Betic Cordillera. The general hydrogeological setting of the study site is described in (IGME, 1988). The basin, situated at an altitude of about 550 masl, is bounded to the east by the Sierra Nevada mountains reaching 3470 masl (Fig. 1) leading to considerable temperature and precipitation gradients. The average temperature in the Granada basin lies between 15 and $16^{\circ} \mathrm{C}$, while in the high regions of the Sierra Nevada (meteorological station Albergue Universitario, 2550 masl) average temperatures range between 5 and $6{ }^{\circ} \mathrm{C}$. The mean annual precipitation ranges between $490 \mathrm{~mm} / \mathrm{a}$ in Granada basin and about $1000 \mathrm{~mm} / \mathrm{a}$ in the upper mountains (IGME, 1988). More than $75 \%$ of the precipitation in the Sierra Nevada above 2000 masl falls as snow (Castillo, 2000).

The basin itself is filled with Miocene, Pliocene and Quaternary sediments. The general Neogene sedimentary sequence consists of calcarenites, terrigeneous sediments and evaporites containing gypsum, especially in the southern area. The Quaternary material forms the Vega de Granada aquifer and consists mainly of fluvial deposits. The aquifer surface occupies an area of approximately $200 \mathrm{~km}^{2}(22 \mathrm{~km} \times 8 \mathrm{~km})$, and its centre is approximately $250 \mathrm{~m}$ thick (Castillo, 2005). The Granada 


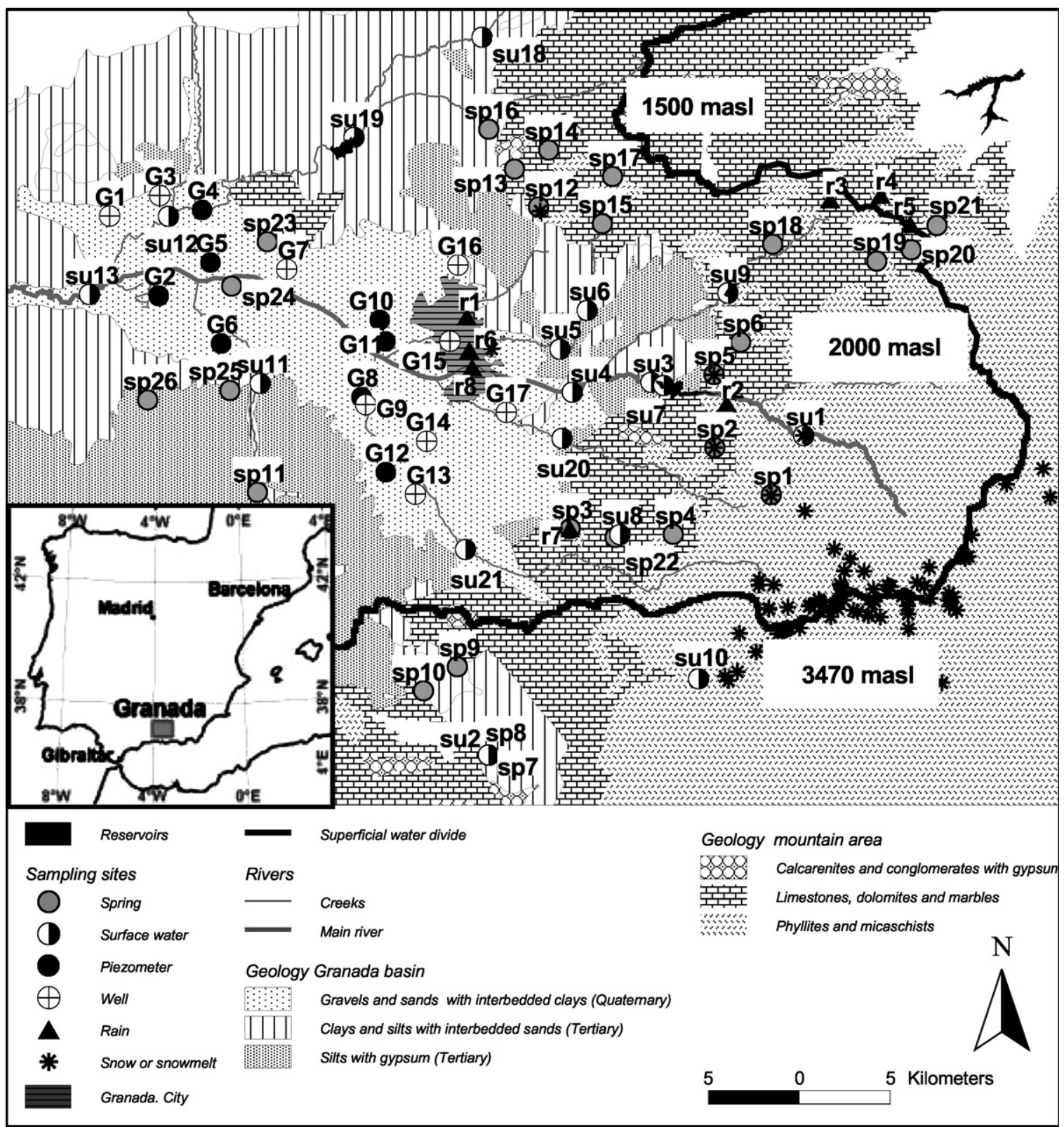

Fig. 1. Location map and sampling sites. Geology was simplified after IGME (1988). The superficial water divide was based on DEM (1999). Abbreviations su, G and sp stand for surface water, groundwater and springs, respectively. Labels of sampling sites refer to Table 2.

basin is separated from the adjacent mountain ranges to the east by a system of normal faults. The lower mountain ranges belong to the Alpujarride Complex, which constitutes an important karstic aquifer in the surroundings of the Granada basin. This aquifer is generally made up of a thick series of Triassic carbonate rocks with intercalated calcschists of low permeability. The higher moun- tain areas which continue to the east belong to the Nevado-Filabride Complex and consist mainly of almost impermeable micaschists.

Discharge of groundwater occurs at about 25 major springs within a range between 0.2 and $12,000 \mathrm{~L} \mathrm{~min}^{-1}$. The major springs are mainly located in the Granada basin, except Fuente Grande (sp12), some being thermal springs (sp8, sp11, sp23, sp25, 
sp27, see Fig. 1). The mountain springs, which are normally located at the contact between carbonates and calcschists, show comparatively low discharge rates below $10 \mathrm{~L} \mathrm{~min}^{-1}$.

The main river, Genil, drains the basin with a mean discharge of $200 \times 10^{6} \mathrm{~m}^{3} / \mathrm{a}$ at the western border of the basin and is recharged by its three main tributaries the Dilar River, Cubillas River and Monachil River, each with a mean annual discharge of $50 \times 10^{6} \mathrm{~m}^{3}$ (Fig. 1). These rivers drain away after entering the basin, recharging the aquifer by bankfiltration and passing through an unsaturated zone of several tens of metres (IGME, 1988). Towards the west the aquifer thickness decreases considerably leading to an important groundwater discharge of about $190 \times 10^{6} \mathrm{~m}^{3}$ into the Genil River. A total annual aquifer recharge of $230 \times 10^{6} \mathrm{~m}^{3}$ was estimated by IGME (1988) where $200 \times 10^{6} \mathrm{~m}^{3}$ of recharge are assumed to occur mainly by river bankfiltration and irrigation channels and $30 \%$ are supposed to be recharged by precipitation. Lateral recharge of the aquifer by subsurface runoff from the karstic aquifer of the eastern mountains has been considered to be of minor importance, but owing to the lack of groundwater sampling locations in the karstic aquifer no estimations exist so far. Tritium measurements carried out by Plata Bedmar and Greciano González (2000) in the aquifer yielded more than 13.5 TU in the central part of the aquifer and even higher values towards the east indicating recharge ages less than 45 a.

An instructive overview of land use and studies carried out in the Vega de Granada aquifer during the last decades is given in Castillo (2005). Groundwater extraction of the Vega de Granada aquifer for agricultural irrigation and drinking water supply started in the second half of the 20th century. It has been intensified considerably since the 1970 s and now reaches about $40 \times 10^{6} \mathrm{~m}^{3}$ annually. Pumping and irrigation increased with the construction of several water reservoirs (e.g. Canales, Cubillas and Quentar) in the watershed, reducing groundwater recharge derived from snow melting in Sierra Nevada (Fig. 1). The hydrodynamic impact of groundwater extraction gave rise to an average drawdown of $6 \mathrm{~m}$ with local maxima up to $20 \mathrm{~m}$ (Fig. 2). Furthermore the development of a drawdown cone in the southeastern part of the aquifer was observed.

Between 1983 and 2004 the electrical conductivity increased more than 25\% (Castillo and Sanchez

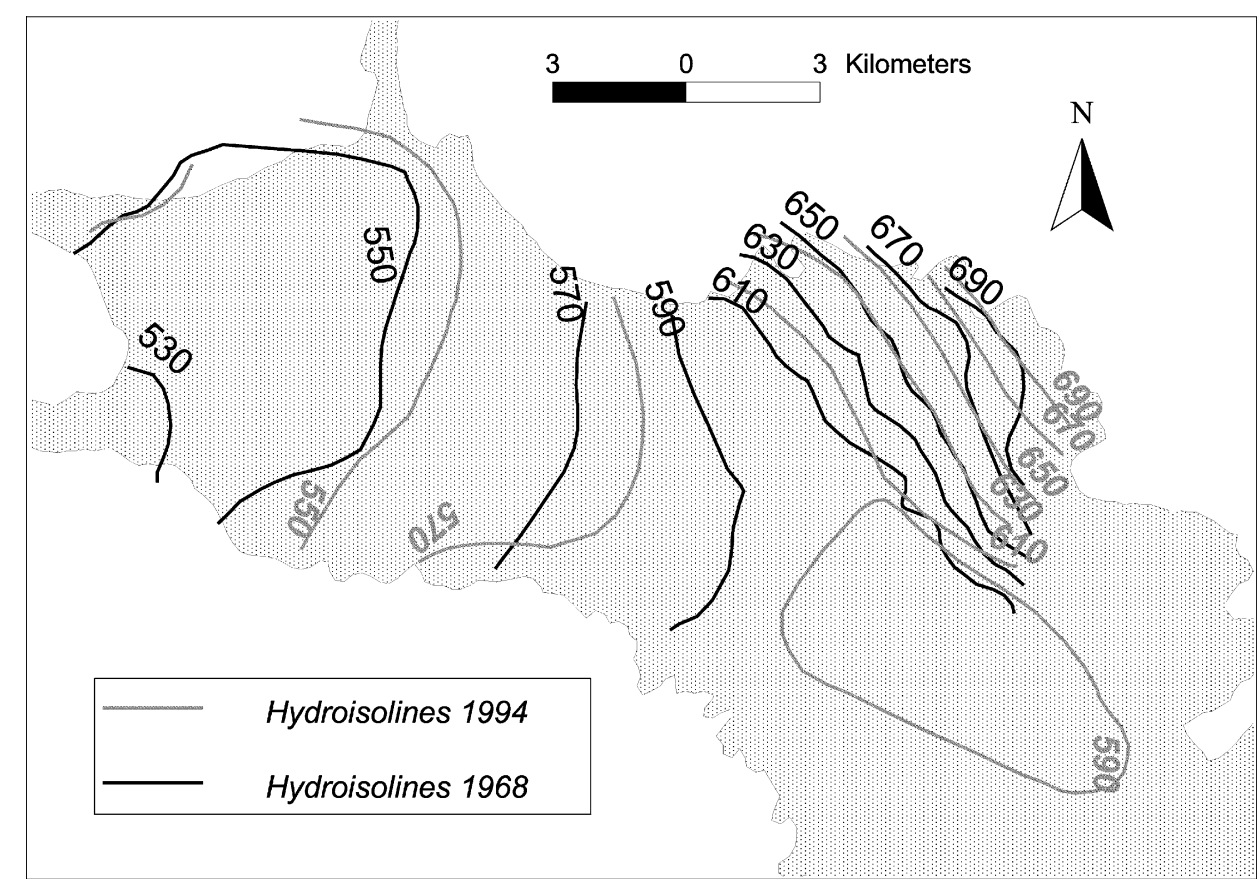

Fig. 2. Hydroisolines of piezometric levels in the Vega de Granada aquifer after Castillo (2005). Hydroisolines of 1968 show a trend map derived from averaged values over the whole year and represent conditions with little groundwater extraction. Isolines of 1994 are interpolated from measurements carried out in March 1994. Elevations are given in masl. 
Diáz, 2005). Agricultural fertilisers and waste deposits from sewage treatment plants resulted in a rise of $\mathrm{NO}_{3}^{-}$concentrations of more than $70 \%$ between 1984 and 2004, leading to an average concentration of about $70 \mathrm{mg} / \mathrm{L}$.

The source regions of precipitation in the study area are the Atlantic Ocean and the western Mediterranean Sea. Isotopic studies in the western Mediterranean are rare, and therefore the relative proportion of Atlantic versus Mediterranean rainfall is only known for very few sites. Based on Mediterranean precipitation Celle-Jeanton and Travi (2001) defined the western Mediterranean waterline (WMMWL) which is typically aligned in a $\delta D_{-}$ $\delta 180$ diagram on a local meteoric water line with a $D$ excess of $+15 \%$ and a slope close to 8 . In contrast, Atlantic precipitation plots on the global meteoric water line (GMWL) with an excess of $+10 \%$. More isotopic data about regional precipitation are available on the Internet in the framework of the global network of isotopes in precipitation (IAEA/WMO, 2001). The $\delta$-values for precipitation are available for Barcelona from January 1984 to December 1991, for Madrid from January 1988 to December 1989, and for Gibraltar from January 1962 to December 1995.

Between May 1999 and July 2001 about 250 samples of atmospheric vapour were analysed by Raya Garrido (2003) for the stable isotope composition of water. The samples were taken every $2-3$ months at different altitudes and orientations of the Sierra Nevada and in the Granada basin. From these data Raya Garrido (2003) derived local meteoric vapour lines and altitude gradients for Granada and for the Sierra Nevada.

Furthermore, monthly precipitation samples were taken by Raya Garrido (2003) between 1996 and 2002 at five locations with different altitudes. On the basis of weighted monthly averaged isotope data of precipitation (Raya Garrido, 2003) derived a local meteoric water line (LMWL) for Granada City:

$\delta^{2} \mathrm{H}=6.9 * \delta^{18} \mathrm{O}+2$ (LMWL Granada)

The slope which is less than eight concurs with the data of IAEA/WMO (2001) taken at the Gibraltar station. According to Raya Garrido (2003) this indicates that the precipitation was subjected to evaporation on its way to the ground surface. However, it is possible that the slope of less than 8 is in fact a mixing line joining a pole of Mediterranean water vapour to a pole of Atlantic water vapour. Raya
Garrido (2003) explains the comparatively low $D$ excess by evaporation of rain before reaching the surface and by an Atlantic source of precipitation. Since sampling points of are all located at different orientations of the Sierra Nevada, no altitude gradients could be derived from these data.

\section{Methods}

Water samples in the Granada region were collected for stable isotope studies $\left({ }^{18} \mathrm{O}\right.$, D) and, in the case of ground- and surface waters, also for major $\left(\mathrm{Ca}^{2+}, \mathrm{Mg}^{2+}, \mathrm{Na}^{+}, \mathrm{K}^{+}, \mathrm{Cl}^{-}, \mathrm{SO}_{4}^{2-}, \mathrm{NO}_{3}^{-}\right)$ and minor ion $\left(\mathrm{Fe}^{2+}, \mathrm{Mn}^{2+}, \mathrm{Sr}^{2+}\right)$ analysis. Sites are located within the Neogene sediments of the Granada basin and the surrounding eastern mountains (Sierra Nevada, Sierra Arana, Sierra PadulLa Peza).

Details of the sampling campaigns are compiled in Table 1. Thirty-seven springs were sampled from October 2004 to March 2005 between 2 and 5 times along an altitudinal gradient from 552 masl in the Granada basin to 2156 masl in the Sierra Nevada. Furthermore, between November 2004 and February 2005, nine groundwater samples were taken from the discharge of operating wells in the Granada basin, which are all located between 728 and 540 masl. The wells and piezometers show depths between 16 and $100 \mathrm{~m}$ and are all constructed within the Quaternary sediments dominated by sands, clays and conglomerates. Additionally eight samples from piezometers taken by a plastic ladle were provided by the Geological Survey of Spain (Instituto Geológico y Minero de España) for isotope analysis. Five reservoirs with altitudinal gradients between 640 and 1010 masl were sampled in

Table 1

Overview of sampling campaigns in chronological order and measured parameters

\begin{tabular}{|c|c|c|c|}
\hline Number & Date & Parameters & Type \\
\hline 13 & February 04 & $\begin{array}{l}\text { Isotopes/ } \\
\text { ions }\end{array}$ & $\begin{array}{l}\text { Springs/snow or } \\
\text { snowmelt }\end{array}$ \\
\hline 4 & May 04 & Isotopes & Springs \\
\hline 73 & $\begin{array}{l}\text { June } 04- \\
\text { September } 04\end{array}$ & Isotopes & Snow or snowmelt \\
\hline 10 & November 04 & Isotopes & Observation wells \\
\hline 5 & December 04 & Isotopes & Rainwater \\
\hline 3 & February 05 & Isotopes & Snow \\
\hline 13 & February 05 & $\begin{array}{l}\text { Isotopes/ } \\
\text { ions }\end{array}$ & $\begin{array}{l}\text { Wells/springs/ } \\
\text { surface water }\end{array}$ \\
\hline 105 & $\begin{array}{l}\text { October 04- } \\
\text { March } 05\end{array}$ & $\begin{array}{l}\text { Isotopes/ } \\
\text { ions }\end{array}$ & $\begin{array}{l}\text { Surface water/ } \\
\text { precipitation }\end{array}$ \\
\hline
\end{tabular}


November/December 2004 and February/March 2005. Samples from nine different rivers and creeks were taken in February/March 2005. The two main rivers were monitored every $2-3$ weeks at three different altitudes ranging from 725 to 1179 masl. Owing to scarce rainfall during the sampling period, precipitation could only be sampled during four rainfall events. Two rainfall events were sampled at altitudes ranging from 650 to 1550 masl and 650 to 1295 masl, respectively. The other events were only collected in Granada city at 650 masl altitude. During June to September 2004, 73 samples of snow or snowmelt were taken mostly in small mountain lakes located in the Sierra Nevada above 2200 masl.

All samples were stored in polypropylene bottles $(50 \mathrm{~mL})$ with watertight caps. Surface- and groundwater samples were filtered immediately after sample retrieval for analysis of cations and anions using $0.45 \mu \mathrm{m}$ membrane filters. Samples for cation analysis were preserved with concentrated $\mathrm{HNO}_{3}$. Measurements for $\mathrm{pH}$, temperature and conductivity were carried out in the field. In most cases alkalinity of filtered samples was determined in the field by titration with $\mathrm{HCl}(0.1 \mathrm{M})$; otherwise, alkalinity samples were collected in glass bottles which were carefully filled without any air entrapment for analysis in the laboratory. After sampling all samples were stored at $4{ }^{\circ} \mathrm{C}$.

Major cation analysis of pore water was carried out on acidified samples using ICP-AES (Perkin Elmer AAS 5000), whereas major anions were determined using ion chromatography (Dionex DX-100). Iron was analysed as total Fe. The analysis of the stable isotopes of water were carried out at the Alfred Wegener Institute in Potsdam using a common equilibration technique with a Finnigan MAT Delta-S mass spectrometer equipped with two equilibration units for the online determination of $\mathrm{H}$ and $\mathrm{O}$ isotopic composition (Meyer, 2000). The concentrations are given hereafter in $\delta$-units calculated with respect to VSMOW (Vienna Standard Mean Ocean Water) expressed in \%o.

$\delta(\% o)=1000\left(\frac{R_{\text {sample }}-R_{\mathrm{VSMOW}}}{R_{\mathrm{VSMOW}}}\right)$

where $R_{\text {sample }}$ and $R_{\text {VSMOW }}$ are the isotopic ratios of the sample and of VSMOW, respectively. The external errors of long-term standard measurements for $\mathrm{H}$ and $\mathrm{O}$ are better than $0.8 \%$ and $0.10 \%$, respectively.
Saturation indices of analysed water samples for calcite, dolomite and gypsum were calculated by the PHREEQCI software, version 2.8 (Parkhurst and Appelo, 1999).

\section{Results and discussion}

\subsection{Major ions}

The ion composition of all analysed samples is compiled in Table 2. A large number of all sampled waters are dominated by $\mathrm{Ca}, \mathrm{Mg}$ and $\mathrm{HCO}_{3}^{-}$ according to their common origin from the carbonate bearing units of the Sierra Nevada (Fig. 3). Therefore the mineralisation of the water samples is directly related to alkalinity and $\mathrm{Ca}$ concentrations. Nonetheless, the thermal springs and also one groundwater sample (G16) show higher relative amounts of $\mathrm{SO}_{4}^{2-}$. One river sample (su11) was enriched in both $\mathrm{Na}$ and $\mathrm{Cl}^{-}$, from anthropogenic sources.

A scatter plot of $\mathrm{Ca}$ versus $\mathrm{HCO}_{3}^{-}$indicates that the chemical evolution of the water is characterised by interaction with carbonate rocks (Fig. 4). Dissolved $\mathrm{CO}_{2}$ reacts with the carbonate rocks in the aquifer, dissolving calcite and dolomite according to the following reactions:

$$
\begin{aligned}
& \mathrm{CaCO}_{3}+\mathrm{CO}_{2}+\mathrm{H}_{2} \mathrm{O}=\mathrm{Ca}^{2+}+2 \mathrm{HCO}_{3}^{-} \\
& \mathrm{CaMg}^{2}\left(\mathrm{CO}_{3}^{2-}\right)_{2}+2 \mathrm{CO}_{2}+2 \mathrm{H}_{2} \mathrm{O} \\
& =\mathrm{Ca}^{2+}+\mathrm{Mg}^{2+}+4 \mathrm{HCO}_{3}
\end{aligned}
$$

Much higher $\mathrm{Ca} / \mathrm{HCO}_{3}^{-}$ratios were only found in thermal springs and are due to gypsum dissolution, whereas the elevated $\mathrm{Ca} / \mathrm{HCO}_{3}^{-}$ratio of the river sample (su11) is again caused by anthropogenic activity.

The spatial distribution of major ion concentrations is consistent with the hydrogeological setting described earlier (Fig. 5). Mineralisation ranges from $40 \mathrm{mg} \mathrm{L}^{-1}$ in high mountain areas to $10 \mathrm{~g} \mathrm{~L}^{-1}$ in the contaminated Arroyo Salado River (su11). The similarity of samples taken from springs in carbonate host rocks in the mountain area with samples taken from Quaternary sediments of the eastern part of the Granada basin indicates an important discharge from the mountain areas into the basin. Water samples taken from the western part of the Granada basin show higher mineralisation and higher $\mathrm{SO}_{4}^{2-}$ concentrations owing to the influence of $\mathrm{SO}_{4}^{2-}$ bearing tertiary sediments. 
Table 2

Main characteristics and chemical composition of sampled water

\begin{tabular}{|c|c|c|c|c|c|c|c|c|c|c|c|c|c|c|c|c|c|c|}
\hline Label & Type & East & North & Altitude & Date & $\begin{array}{l}\text { Temperature } \\
\left({ }^{\circ} \mathrm{C}\right)\end{array}$ & $\begin{array}{l}\mathrm{EC} \mu \mathrm{s} / \\
\mathrm{cm}\end{array}$ & $\mathrm{pH}$ & $\begin{array}{l}Q(\mathrm{~L} / \\
\min )\end{array}$ & $\mathrm{Ca}$ & $\mathrm{Mg}$ & $\mathrm{Na}$ & $\mathrm{K}$ & $\mathrm{Cl}^{-}$ & $\mathrm{SO}_{4}^{2-}$ & $\mathrm{HCO}_{3}^{-}$ & $\mathrm{NO}_{3}^{-}$ & $\begin{array}{l}\text { Well } \\
\text { depth }\end{array}$ \\
\hline G13 & Well & 444185 & 4106797 & 814 & $2 / 18 / 2005$ & 15 & 575 & 7.5 & 3300 & 3.54 & 2.22 & 0.44 & 0.03 & 0.34 & 0.79 & 4.87 & 0.26 & 90 \\
\hline G14 & Well & 444801 & 4109716 & 694 & $2 / 18 / 2005$ & 15 & 735 & 7.3 & 900 & 4.29 & 3.70 & 0.47 & 0.06 & 0.82 & 1.96 & 5.29 & 0.69 & \\
\hline G16 & Well & 446535 & 4119370 & 724 & $2 / 18 / 2005$ & 15 & 1701 & 7.0 & & 11.98 & 8.64 & 0.86 & 0.08 & 0.79 & 14.89 & 5.14 & 0.65 & 16 \\
\hline G17 & Well & 449190 & 4111289 & 719 & $2 / 18 / 2005$ & 14 & 824 & 7.5 & & 4.84 & 3.95 & 0.52 & 0.06 & 0.56 & 2.12 & 5.55 & 0.68 & \\
\hline G7 & Well & 437121 & 4119131 & 574 & $2 / 18 / 2005$ & 16 & 941 & 7.3 & & 5.14 & 4.69 & 0.73 & 0.05 & 0.65 & 3.91 & 5.16 & 0.55 & 16 \\
\hline G9 & Well & 441457 & 4111726 & 654 & $2 / 18 / 2005$ & 14 & 828 & 7.4 & 2400 & 7.24 & 3.46 & 0.52 & 0.04 & 2.54 & 3.75 & 4.53 & 0.53 & 60 \\
\hline sp1 & Spring & 463724 & 4106755 & 2156 & $2 / 5 / 2004$ & 7 & 138 & & & 0.52 & 0.33 & 0.40 & 0.01 & 0.76 & 0.06 & 0.37 & 0.01 & \\
\hline sp1 & Spring & 463724 & 4106755 & 2156 & $10 / 7 / 2004$ & 8 & 77 & 7.8 & 6 & 0.31 & 0.25 & 0.11 & 0.00 & 0.20 & 0.04 & 0.42 & 0.02 & \\
\hline sp10 & Spring & 444626 & 4096002 & 730 & $2 / 6 / 2004$ & 17 & 533 & & & 2.99 & 2.80 & 0.23 & 0.05 & 0.25 & 0.73 & 4.78 & 0.12 & \\
\hline sp10 & Spring & 444626 & 4096002 & 730 & $10 / 16 / 2004$ & 17 & 630 & 7.5 & & 2.94 & 2.72 & 0.24 & 0.05 & 0.23 & 0.69 & 4.78 & 0.13 & \\
\hline sp11 & Spring & 435500 & 4106901 & 752 & $2 / 6 / 2004$ & 21 & 3090 & & & 16.47 & 9.05 & 11.09 & 0.26 & 11.56 & 22.90 & 3.03 & 0.01 & \\
\hline sp11 & Spring & 435500 & 4106901 & 752 & $10 / 16 / 2004$ & 26 & 3500 & 7.2 & 7600 & 15.77 & 7.41 & 10.31 & 0.24 & 9.31 & 20.86 & 3.03 & 0.00 & \\
\hline sp12 & Spring & 450942 & 4122562 & 1114 & $2 / 6 / 2004$ & 13 & 415 & & 9000 & 2.69 & 1.65 & 0.05 & 0.01 & 0.06 & 0.31 & 4.18 & 0.04 & \\
\hline sp12 & Spring & 450942 & 4122562 & 1114 & $10 / 7 / 2004$ & 12 & 446 & 7.7 & 9000 & 2.74 & 1.73 & 0.06 & 0.01 & 0.07 & 0.29 & 4.31 & 0.06 & \\
\hline sp13 & Spring & 449618 & 4124631 & 1108 & $10 / 7 / 2004$ & 12 & 505 & 7.4 & 900 & 3.29 & 1.77 & 0.03 & 0.01 & 0.08 & 1.25 & 3.95 & 0.05 & \\
\hline sp14 & Spring & 451504 & 4125682 & 1115 & $10 / 7 / 2004$ & 12 & 412 & 7.2 & & 2.74 & 1.44 & 0.09 & 0.01 & 0.06 & 0.23 & 3.89 & 0.03 & \\
\hline sp15 & Spring & 454448 & 4121644 & 1106 & $10 / 7 / 2004$ & 13 & 438 & 7.7 & & 2.64 & 1.73 & 0.05 & 0.01 & 0.04 & 0.31 & 4.04 & 0.03 & \\
\hline sp16 & Spring & 448211 & 4126823 & 944 & $11 / 8 / 2004$ & 14 & 854 & 7.0 & 100 & 5.24 & 2.57 & 0.20 & 0.04 & 0.24 & 0.83 & 6.09 & 0.56 & \\
\hline sp17 & Spring & 455011 & 4124238 & 1262 & $11 / 8 / 2004$ & 13 & 722 & 7.0 & 0 & 4.09 & 3.46 & 0.09 & 0.01 & 0.10 & 0.15 & 7.04 & 0.01 & \\
\hline sp18 & Spring & 463808 & 4120518 & 1113 & $11 / 9 / 2004$ & 13 & 755 & 7.3 & 18 & 4.54 & 3.29 & 0.06 & 0.01 & 0.08 & 2.23 & 5.19 & 0.05 & \\
\hline sp19 & Spring & 469515 & 4119592 & 1362 & $11 / 9 / 2004$ & 11 & 436 & 7.7 & 43 & 2.55 & 1.69 & 0.04 & 0.01 & 0.06 & 0.09 & 3.89 & 0.11 & \\
\hline $\mathrm{sp} 2$ & Spring & 460619 & 4109365 & 1629 & $2 / 5 / 2004$ & 9 & 284 & & & 2.05 & 1.00 & 0.15 & 0.01 & 0.25 & 0.12 & 2.66 & 0.03 & \\
\hline $\mathrm{sp} 2$ & Spring & 460619 & 4109365 & 1629 & $10 / 7 / 2004$ & 11 & 288 & 7.1 & 1 & 2.00 & 1.01 & 0.16 & 0.01 & 0.24 & 0.10 & 2.66 & 0.05 & \\
\hline sp20 & Spring & 471406 & 4120195 & 1605 & $11 / 9 / 2004$ & 10 & 276 & 7.8 & 360 & 1.75 & 0.94 & 0.04 & 0.01 & 0.06 & 0.16 & 2.39 & 0.04 & \\
\hline $\mathrm{sp} 21$ & Spring & 472835 & 4121540 & 1471 & $11 / 9 / 2004$ & 10 & 309 & 8.2 & & 2.55 & 0.36 & 0.05 & 0.01 & 0.06 & 0.07 & 2.77 & 0.08 & \\
\hline $\mathrm{sp} 21$ & Spring & 472835 & 4121540 & 1471 & $11 / 9 / 2004$ & 10 & 309 & 8.2 & & 2.55 & 0.36 & 0.05 & 0.01 & 0.06 & 0.07 & 2.77 & 0.08 & \\
\hline sp22 & Spring & 455151 & 4104428 & 1411 & $11 / 22 / 2004$ & 9 & 507 & 7.9 & & 2.89 & 2.24 & 0.05 & 0.01 & 0.05 & 0.15 & 5.16 & 0.01 & \\
\hline sp22 & Spring & 455151 & 4104428 & 1411 & $11 / 22 / 2004$ & 9 & 507 & 7.9 & & 2.89 & 2.24 & 0.05 & 0.01 & 0.05 & 0.15 & 5.16 & 0.01 & \\
\hline sp23 & Spring & 436043 & 4120641 & 571 & $2 / 18 / 2005$ & 32 & 2650 & 7.3 & 10800 & 13.47 & 9.05 & 7.87 & 0.29 & 7.90 & 18.74 & 5.12 & 0.18 & 20 \\
\hline sp24 & Spring & 434096 & 4118218 & 563 & $2 / 18 / 2005$ & 15 & 1125 & 7.1 & 12000 & 6.74 & 3.46 & 2.17 & 0.09 & 1.27 & 3.12 & 7.24 & 0.55 & \\
\hline sp25 & Spring & 433992 & 4112505 & 840 & $2 / 18 / 2005$ & 37 & 3700 & 7.0 & & 29.94 & 15.63 & 7.48 & 0.37 & 6.49 & 46.64 & 2.69 & 0.08 & \\
\hline sp26 & Spring & 429477 & 4111979 & 542 & $2 / 18 / 2005$ & 15 & 1042 & 7.3 & 1200 & 5.79 & 4.53 & 1.26 & 0.06 & 1.02 & 3.75 & 6.08 & 0.61 & \\
\hline sp3 & Spring & 452680 & 4104908 & 1292 & $2 / 5 / 2004$ & 12 & 286 & & & 2.25 & 0.84 & 0.08 & 0.01 & 0.06 & 0.27 & 2.60 & 0.10 & \\
\hline sp3 & Spring & 452680 & 4104908 & 1292 & $10 / 7 / 2004$ & 11 & 289 & 7.1 & & 2.00 & 0.78 & 0.08 & 0.01 & 0.06 & 0.27 & 2.50 & 0.08 & \\
\hline sp4 & Spring & 458341 & 4104600 & 1695 & $2 / 5 / 2004$ & 9 & 401 & & & 2.35 & 2.14 & 0.05 & 0.01 & 0.06 & 0.12 & 4.47 & 0.01 & \\
\hline sp4 & Spring & 458341 & 4104600 & 1695 & $10 / 7 / 2004$ & 8 & 440 & 8.2 & 1 & 2.35 & 2.55 & 0.19 & 0.03 & 0.06 & 0.07 & 4.77 & 0.02 & \\
\hline sp5 & Spring & 460592 & 4113364 & 1222 & $2 / 5 / 2004$ & 12 & 262 & & & 1.75 & 1.11 & 0.04 & 0.01 & 0.03 & 0.31 & 2.44 & 0.04 & \\
\hline sp5 & Spring & 460592 & 4113364 & 1222 & $10 / 7 / 2004$ & 11 & 242 & 7.8 & & 1.40 & 0.92 & 0.07 & 0.01 & 0.06 & 0.28 & 2.09 & 0.03 & \\
\hline sp6 & Spring & 462038 & 4115147 & 1278 & $2 / 5 / 2004$ & 12 & 315 & & & 2.30 & 1.11 & 0.05 & 0.01 & 0.06 & 0.31 & 3.19 & 0.04 & \\
\hline sp7 & Spring & 448212 & 4092451 & 650 & $2 / 5 / 2004$ & 24 & 824 & & & 4.99 & 3.87 & 0.43 & 0.05 & 0.48 & 5.10 & 3.93 & 0.01 & \\
\hline sp7 & Spring & 448212 & 4092451 & 650 & $10 / 16 / 2004$ & 23 & 754 & 7.6 & & 4.99 & 3.54 & 0.43 & 0.05 & 0.54 & 4.75 & 3.93 & 0.03 & \\
\hline
\end{tabular}


Table 2 (continued)

\begin{tabular}{|c|c|c|c|c|c|c|c|c|c|c|c|c|c|c|c|c|c|c|}
\hline Label & Type & East & North & Altitude & Date & $\begin{array}{l}\text { Temperature } \\
\left({ }^{\circ} \mathrm{C}\right)\end{array}$ & $\begin{array}{l}\mathrm{EC} \mu \mathrm{s} / \\
\mathrm{cm}\end{array}$ & $\mathrm{pH}$ & $\begin{array}{l}Q(\mathrm{~L} / \\
\min )\end{array}$ & $\mathrm{Ca}$ & $\mathrm{Mg}$ & $\mathrm{Na}$ & $\mathrm{K}$ & $\mathrm{Cl}^{-}$ & $\mathrm{SO}_{4}^{2-}$ & $\mathrm{HCO}_{3}^{-}$ & $\mathrm{NO}_{3}^{-}$ & $\begin{array}{l}\text { Well } \\
\text { depth }\end{array}$ \\
\hline sp8 & Spring & 448216 & 4092453 & 650 & $2 / 5 / 2004$ & 24 & 785 & & & 4.59 & 3.70 & 0.37 & 0.05 & 0.39 & 4.58 & 3.88 & 0.01 & \\
\hline sp8 & Spring & 448216 & 4092453 & 650 & $10 / 16 / 2004$ & 23 & 834 & 7.7 & & 4.59 & 3.29 & 0.39 & 0.05 & 0.34 & 4.43 & 3.73 & 0.13 & \\
\hline sp9 & Spring & 446488 & 4097321 & 745 & $2 / 6 / 2004$ & 15 & 473 & & 110 & 2.84 & 2.47 & 0.09 & 0.02 & 0.08 & 0.83 & 4.13 & 0.11 & \\
\hline sp9 & Spring & 446488 & 4097321 & 745 & $10 / 16 / 2004$ & 16 & 505 & 7.7 & 100 & 2.74 & 2.39 & 0.10 & 0.02 & 0.10 & 0.77 & 4.13 & 0.10 & \\
\hline su1 & Surf. water & 465504 & 4110023 & 1179 & $10 / 7 / 2004$ & 9 & 136 & 8.2 & & 0.75 & 0.35 & 0.11 & 0.01 & 0.03 & 0.48 & 0.73 & 0.01 & \\
\hline sul0 & Surf. water & 459726 & 4096646 & 2500 & $2 / 13 / 2005$ & 6 & 125 & 7.2 & & 0.85 & 0.38 & 0.07 & 0.04 & 0.03 & 0.21 & 1.05 & 0.02 & \\
\hline su11 & Surf. water & 435667 & 4112891 & 740 & $2 / 18 / 2005$ & 5 & 15620 & 8.5 & & 33.43 & 22.05 & 113.96 & 0.77 & 107.19 & 48.93 & 5.28 & 0.39 & \\
\hline su12 & Surf. water & 430629 & 4122035 & 549 & $2 / 18 / 2005$ & 14 & 1501 & 7.2 & & 9.48 & 5.02 & 2.85 & 0.11 & 2.37 & 8.95 & 6.19 & 0.65 & \\
\hline su3 & Surf. water & 457130 & 4112948 & 820 & $11 / 10 / 2004$ & 11 & 130 & 7.3 & & 1.00 & 0.63 & 0.10 & 0.02 & 0.06 & 0.58 & 1.04 & 0.02 & \\
\hline su4 & Surf. water & 452810 & 4112390 & 725 & $11 / 10 / 2004$ & 12 & 380 & 8.1 & & 3.04 & 1.93 & 0.24 & 0.05 & 0.11 & 1.35 & 3.45 & 0.02 & \\
\hline su6 & Surf. water & 453614 & 4116883 & 875 & $11 / 25 / 2004$ & 9 & 540 & 8.2 & & 3.59 & 1.98 & 0.23 & 0.04 & 0.14 & 0.59 & 4.79 & 0.11 & \\
\hline su6 & Surf. water & 453614 & 4116883 & 875 & $11 / 25 / 2004$ & 9 & 540 & 8.2 & & 3.59 & 1.98 & 0.23 & 0.04 & 0.14 & 0.59 & 4.79 & 0.11 & \\
\hline
\end{tabular}

Labels refer to Fig. 1, well depth and altitude are given in m, concentrations are given in meq/L, $Q$ refers to discharge of springs or operating wells during sampling. Rain water and snow or snowmelt analyses are not included.

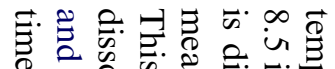

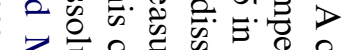
ঊ.

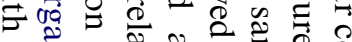

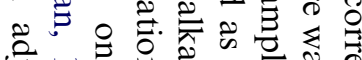

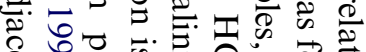
के जे च 。류

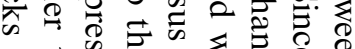

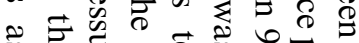
के ०० $\overrightarrow{0} 0 \stackrel{0}{0} \stackrel{0}{0} \stackrel{0}{0}$

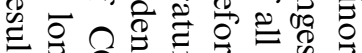

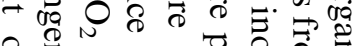

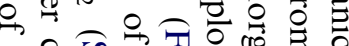

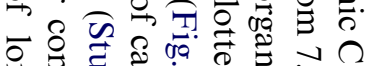

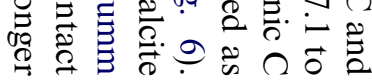

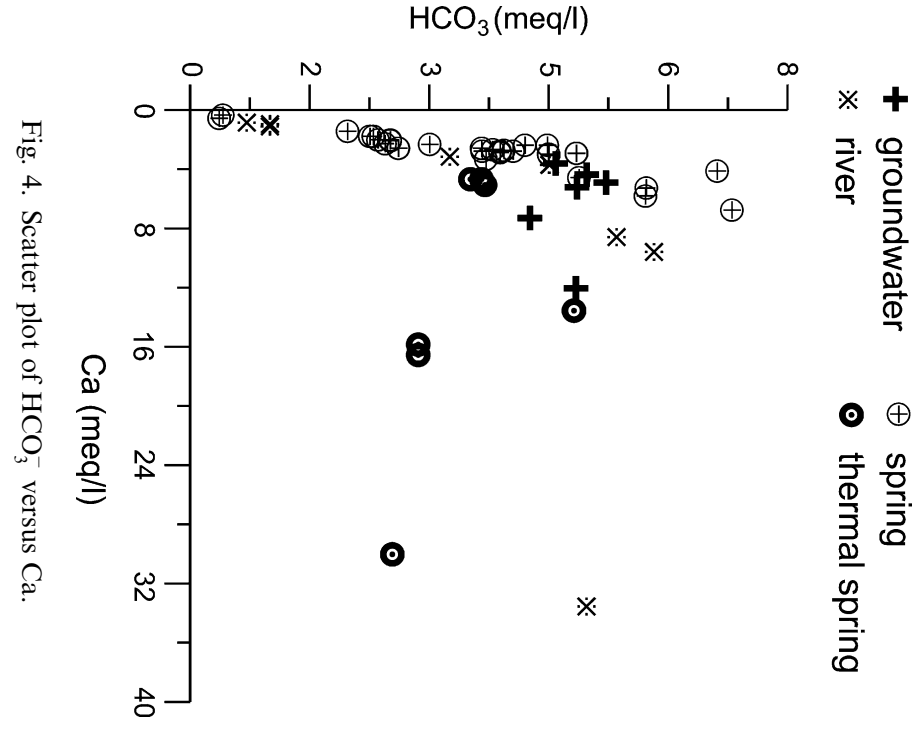

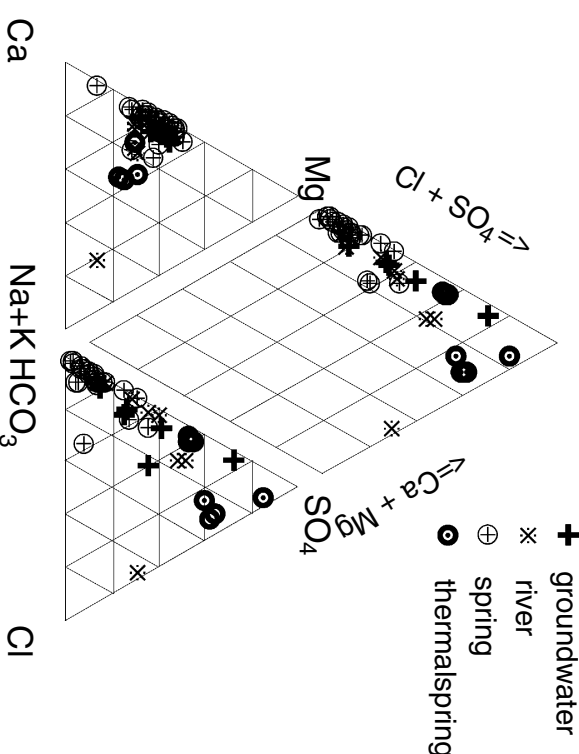




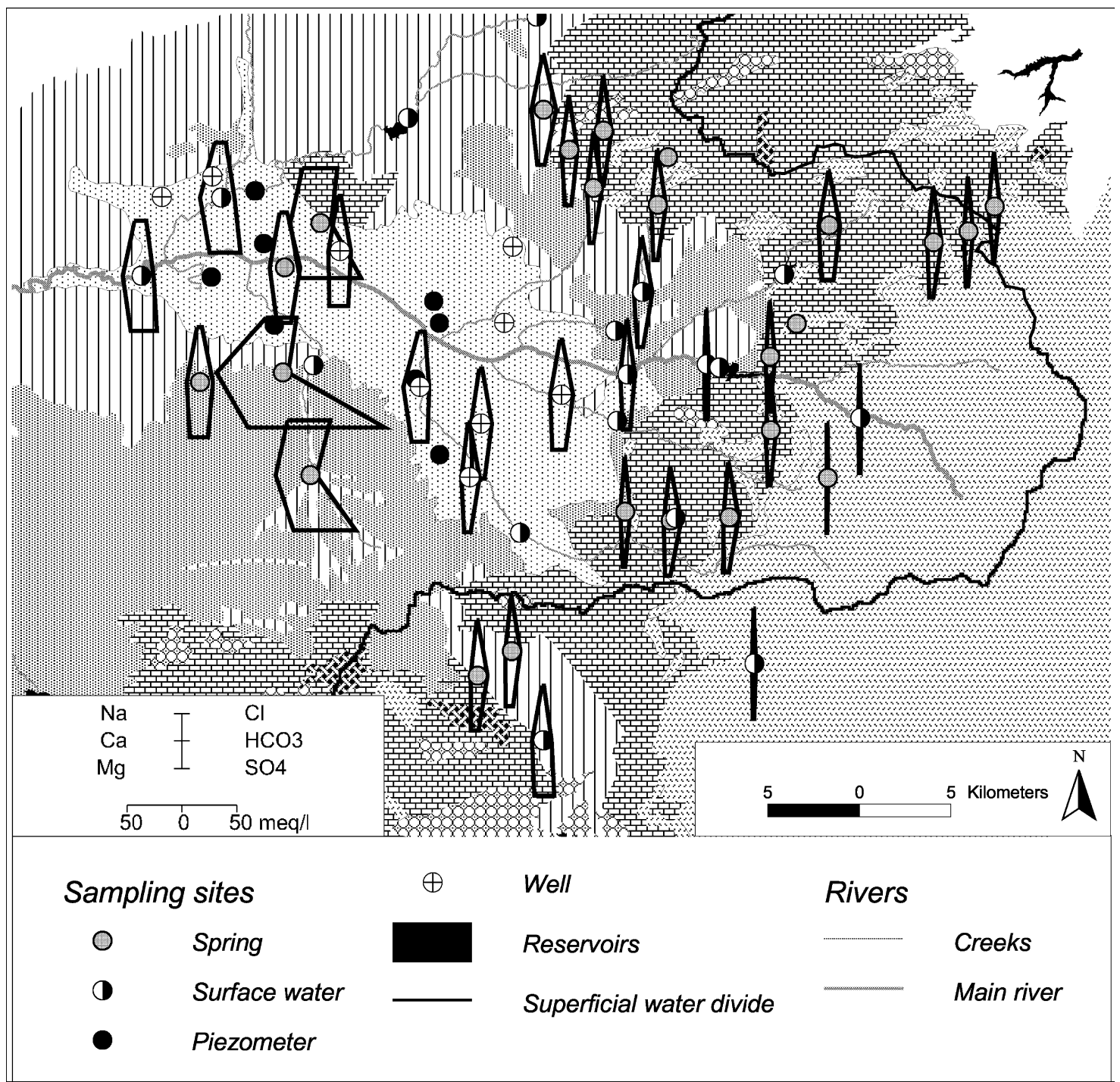

Fig. 5. Relative amounts of major ions analysed in springs, ground- and surface water plotted in stiff diagrams. For geology refer to Fig. 1.

distances to the recharge area. Since the partial pressure of $\mathrm{CO}_{2}$ is controlled by biodegradation in the subsurface it depends on vegetation and therefore on temperature. Infiltrating water is equilibrated immediately with calcite in the unsaturated zone according to the partial pressure of $\mathrm{CO}_{2}$ in soil air. After entering the saturated zone the alkalinity does not change significantly on its flowpath through carbonates. Samples with temperatures higher than $20^{\circ} \mathrm{C}$ (Fig. 6) represent thermal springs and do correlate with alkalinity. In this case water was heated up at greater depths where a higher temperature is not associated with enhanced biodegradation and elevated partial pressure of $\mathrm{CO}_{2}$.
The regional distribution of calcite and dolomite saturation indices is plotted in Fig. 7 and is in concordance with the results discussed above. Colder springs which are located in higher altitudes are undersaturated even if they emanate from carbonate rocks, whereas water samples at lower altitudes in the mountain area and in the Granada basin are mostly over saturated in calcite and dolomite. The dissolution of dolomite is a kinetically controlled process and therefore depends mainly on the contact time between rock and water. Dolomite dissolution adds $\mathrm{Ca}^{2+}, \mathrm{Mg}^{2+}$, and $\mathrm{HCO}_{3}^{-}$to the solution, while calcite precipitation is necessary to keep the observed calcite saturation. Thus, the combination 


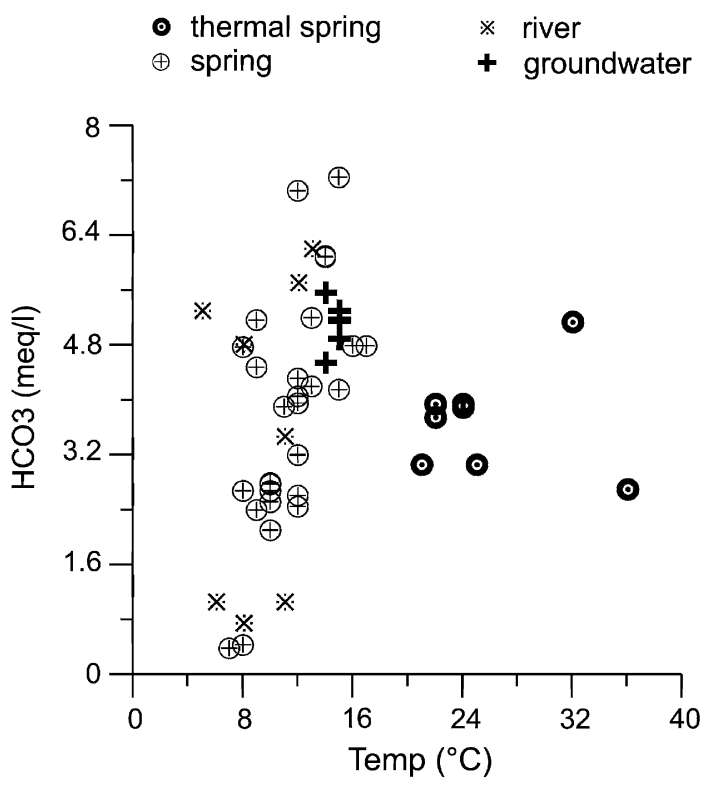

Fig. 6. $\mathrm{HCO}_{3}^{-}$concentrations of spring samples plotted versus temperature.

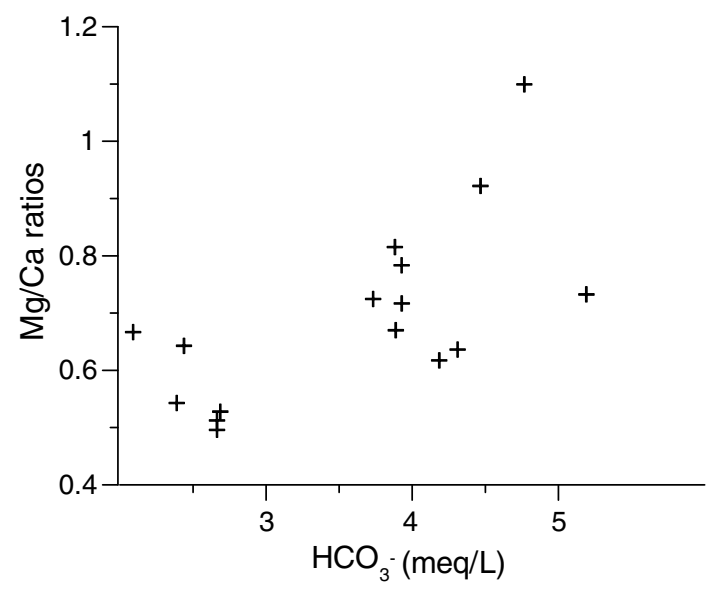

Fig. 8. $\mathrm{Ca} / \mathrm{Mg}$ ratios versus $\mathrm{HCO}_{3}^{-}$in meq/L of water samples from springs located in carbonate rocks containing no gypsum.

of dolomite dissolution and calcite precipitation is thought to increase $\mathrm{Mg} / \mathrm{Ca}$ ratios along flowpaths. This can be observed in Fig. 8, where high elevation

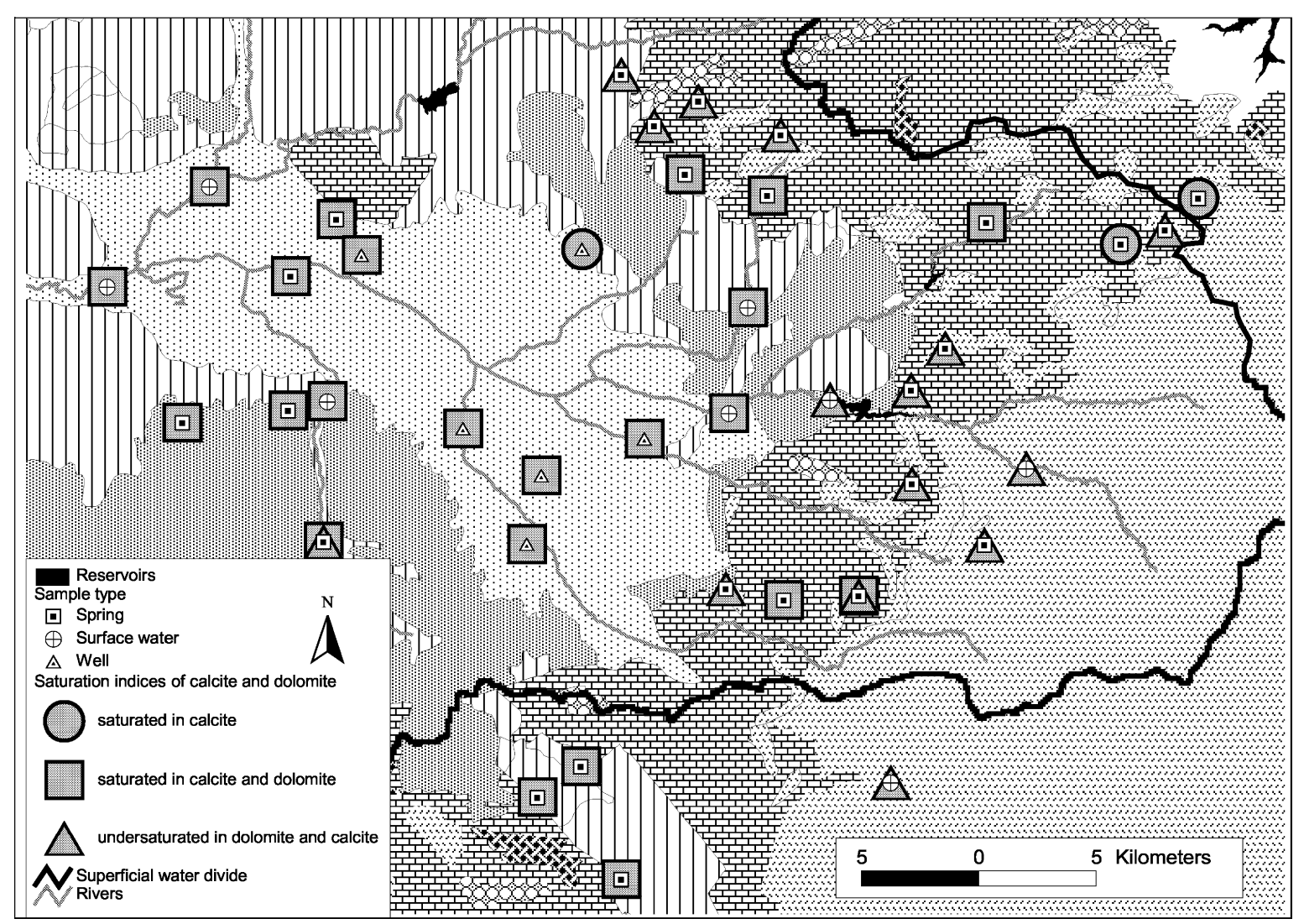

Fig. 7. Map of calcite- and dolomite saturation indices of analysed water sample groups, calculated by the PHREEQCI software, version 2.8 (Parkhurst 1995). For geology refer to Fig. 1. Multiple symbols for saturation indices on one point represent different dates of sampling. 
springs with low $\mathrm{HCO}_{3}$ concentrations have the lowest $\mathrm{Mg} / \mathrm{Ca}$ ratios and low elevation springs further from the recharge area with high $\mathrm{HCO}_{3}^{-}$concentrations show higher $\mathrm{Mg} / \mathrm{Ca}$ ratios.

Saturation indices of gypsum calculated with PHREEQCI (Parkhurst, 1995) yielded undersaturation for all analysed samples but undersaturation close to equilibrium in the samples sul1 and sp 25 (Table 2 and Fig. 1), which is due to their contact with $\mathrm{SO}_{4}^{2-}$ bearing sediments in the Granada basin.

The samples from October 2004 show considerably higher saturation indices than the samples taken in February 2005 owing to the longer residence time of the water, which was sampled after the dry season.

\subsection{Stable isotopes}

Scarce precipitation during the study period gave rise to only eight rain samples which were taken between February 2004 and March 2005 during four rainfall events (Fig. 9). Since no correlation between altitude and $\delta$-values was observed and the number of samples was small, the data were not considered to be suitable for reliable interpretations. Therefore, isotope data from Raya Garrido (2003) were used for the interpretation of the field data. The seasonality of isotope enrichment in precipitation was not considered in this study because

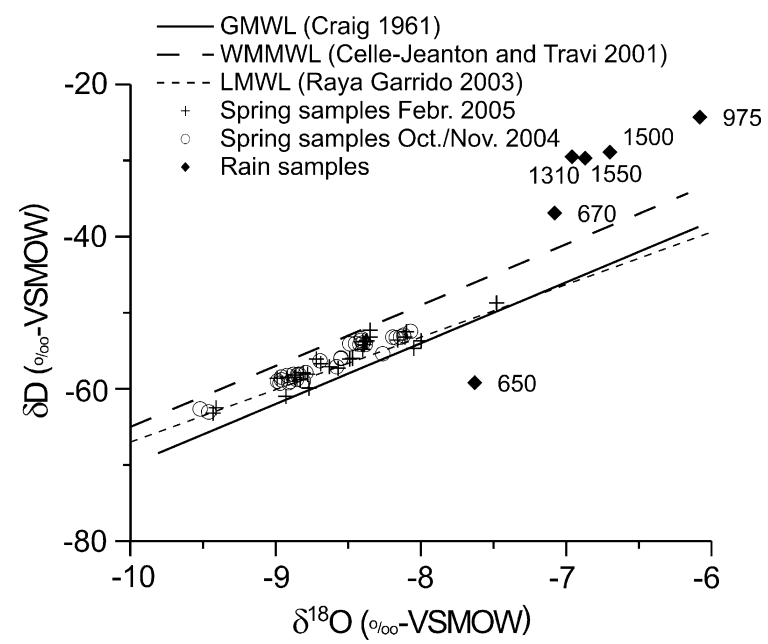

Fig. 9. $\delta D$ versus $\delta^{18} \mathrm{O}$ data for springs, snow melt and rain samples. Springs and snow melt samples were collected between February 2004 and March 2005. Rain samples were taken at different altitudes during a rainfall event in February 2004. The plot labels refer to altitude of the sampling location for rain water in masl. the major part of rainfall occurs during the winter period.

The isotope composition of snow, snowmelt and small lakes (lagunas) in high mountain areas gives valuable information about the effect of melting snow on recharge processes. Fig. 1 shows the localities of 77 samples taken between May and September 2004 classified as snow, snowmelt or laguna type presented in Fig. 10. Most depleted in heavy isotopes are fresh snow samples plotting between WMMWL and GMWL. Snow, snowmelt and most of the laguna plot close to the GMWL and the WMMWL, indicating an evaporative enrichment of heavy isotopes under high humidity conditions. One sample was taken in an endoreic laguna without discharge characterised by strong evaporative enrichment under dry conditions.

Due to the large number of stable isotope analyses only their average values and variances in springs and groundwater are compiled in Table 3. Note that average values are not corrected for discharges in springs. All 72 spring samples are situated between the GMWL and the WMMWL, reflecting the different sources of precipitation which are the Atlantic and the western Mediterranean (Fig. 9). A seasonal trend of different sources cannot be derived from the measurements which were taken mostly in October/November 2004 and February/

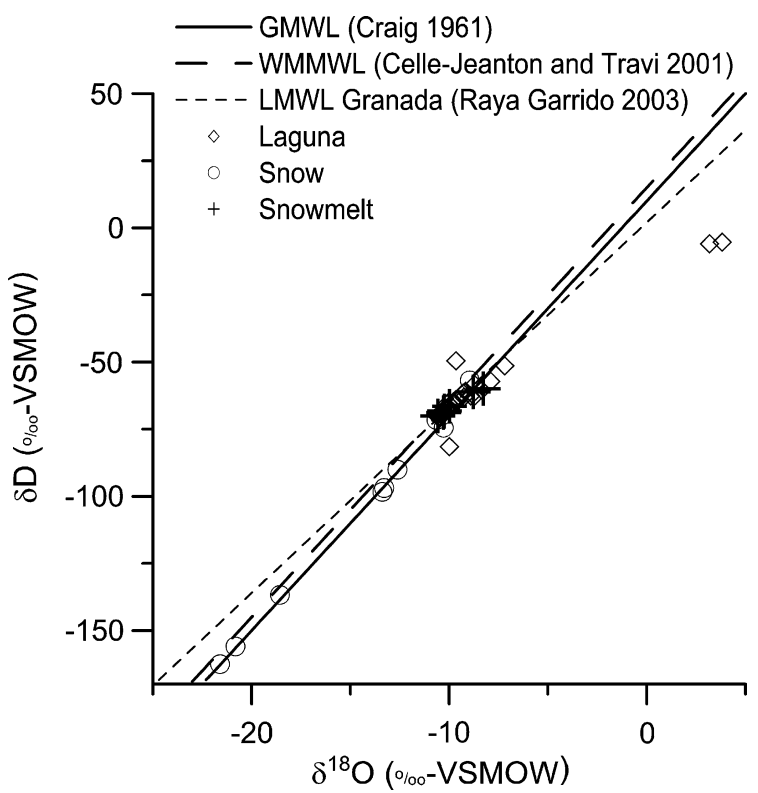

Fig. 10. $\delta D$ versus $\delta^{18} \mathrm{O}$ data for high mountain lakes (lagunas), snow and snow melt samples collected between February 2004 and March 2005. 
Table 3

Statistic data of stable isotope composition for samples taken in springs and groundwater sorted for altitudes

\begin{tabular}{|c|c|c|c|c|c|c|c|c|c|c|}
\hline Label & $\begin{array}{l}\text { Altitude } \\
\text { (MASL) }\end{array}$ & $\begin{array}{l}\text { Number of } \\
\text { measurements }\end{array}$ & $\begin{array}{l}\text { Average of } \\
\delta^{18} \mathrm{O}\end{array}$ & $\begin{array}{l}\text { Maximum } \\
\delta^{18} \mathrm{O}\end{array}$ & $\begin{array}{l}\text { Minimum } \\
\delta^{18} \mathrm{O}\end{array}$ & $\begin{array}{l}\text { Variance of } \\
\delta^{18} \mathrm{O}\end{array}$ & $\begin{array}{l}\text { Average of } \\
\delta D\end{array}$ & $\begin{array}{l}\text { Maximum } \\
\delta D\end{array}$ & $\begin{array}{l}\text { Minimum } \\
\delta D\end{array}$ & $\begin{array}{l}\text { Variance of } \\
\delta D\end{array}$ \\
\hline sp26 & 542 & 1 & -8.44 & & & & -57.07 & & & \\
\hline su12 & 549 & 1 & -6.55 & & & & -45.89 & & & \\
\hline su13 & 560 & 1 & -7.43 & & & & -51.48 & & & \\
\hline sp24 & 563 & 1 & -8.39 & & & & -57.45 & & & \\
\hline $\mathrm{sp} 23$ & 571 & 1 & -7.82 & & & & -51.82 & & & \\
\hline G7 & 574 & 1 & -8.52 & & & & -57.53 & & & \\
\hline sp7 & 650 & 6 & -8.84 & -8.79 & -8.92 & 0.0039 & -58.01 & -57.89 & -58.24 & 0.0319 \\
\hline sp8 & 650 & 6 & -8.84 & -8.78 & -8.88 & 0.0020 & -58.12 & -58.10 & -58.17 & 0.0014 \\
\hline G9 & 654 & 1 & -9.16 & & & & -62.33 & & & \\
\hline G14 & 694 & 1 & -8.98 & & & & -60.22 & & & \\
\hline G17 & 719 & 1 & -8.91 & & & & -60.40 & & & \\
\hline G16 & 724 & 1 & -7.81 & & & & -50.90 & & & \\
\hline su4 & 725 & 5 & -8.54 & -8.35 & -8.71 & 0.0182 & -57.29 & -56.30 & -58.63 & 0.8286 \\
\hline sp10 & 730 & 6 & -8.09 & -8.05 & -8.16 & 0.0027 & -53.58 & -52.45 & -54.70 & 1.0098 \\
\hline su11 & 740 & 1 & -6.53 & -6.53 & -6.53 & & -48.24 & & & \\
\hline sp9 & 745 & 8 & -8.56 & -8.49 & -8.63 & 0.0028 & -56.29 & -55.94 & -57.10 & 0.2507 \\
\hline sp11 & 752 & 8 & -8.47 & -8.26 & -8.58 & 0.0186 & -56.45 & -55.39 & -57.30 & 0.7040 \\
\hline G13 & 814 & 1 & -9.15 & & & & -60.50 & & & \\
\hline su3 & 820 & 6 & -9.20 & -9.01 & -9.53 & 0.0377 & -62.50 & -61.29 & -64.10 & 1.1484 \\
\hline $\mathrm{sp} 25$ & 840 & 1 & -8.41 & & & & -55.31 & & & \\
\hline su6 & 875 & 8 & -8.15 & -8.06 & -8.22 & 0.0045 & -52.44 & -51.62 & -54.30 & 1.3456 \\
\hline sp16 & 944 & 1 & -7.48 & & & & -48.70 & & & \\
\hline sp15 & 1106 & 3 & -8.42 & -8.37 & -8.49 & 0.0039 & -54.19 & -53.70 & -54.80 & 0.3121 \\
\hline sp13 & 1108 & 4 & -8.41 & -8.39 & -8.42 & 0.0002 & -53.95 & -53.62 & -54.20 & 0.0808 \\
\hline sp18 & 1113 & 1 & -8.10 & & & & -52.50 & & & \\
\hline $\mathrm{sp} 12$ & 1114 & 12 & -8.40 & -8.35 & -8.45 & 0.0010 & -53.77 & -53.20 & -54.18 & 0.1350 \\
\hline sp14 & 1115 & 4 & -8.12 & -8.10 & -8.14 & 0.0003 & -52.97 & -52.50 & -53.20 & 0.1089 \\
\hline sul & 1179 & 6 & -9.69 & -9.41 & -10.27 & 0.0905 & -66.12 & -64.30 & -70.79 & 5.5642 \\
\hline sp5 & 1222 & 10 & -8.87 & -8.83 & -8.97 & 0.0028 & -58.68 & -58.08 & -59.26 & 0.1665 \\
\hline sp17 & 1262 & 1 & -8.35 & & & & -52.30 & & & \\
\hline sp6 & 1278 & 3 & -8.12 & -8.00 & -8.19 & 0.0111 & -53.40 & -53.21 & -53.70 & 0.0697 \\
\hline sp3 & 1292 & 12 & -8.87 & -8.77 & -8.93 & 0.0038 & -58.64 & -53.73 & -61.00 & 5.7898 \\
\hline sp19 & 1362 & 1 & -8.55 & & & & -56.70 & & & \\
\hline sp22 & 1411 & 2 & -8.97 & -8.97 & -8.97 & 0.0000 & -59.20 & -59.20 & -59.20 & 0.0000 \\
\hline sp21 & 1471 & 2 & -8.69 & -8.69 & -8.69 & 0.0000 & -56.70 & -56.70 & -56.70 & 0.0000 \\
\hline sp20 & 1605 & 1 & -8.79 & & & & -57.80 & & & \\
\hline $\mathrm{sp} 2$ & 1629 & 6 & -8.97 & -8.92 & -8.99 & 0.0013 & -58.69 & -58.50 & -58.98 & 0.0517 \\
\hline sp4 & 1695 & 10 & -8.84 & -8.69 & -8.96 & 0.0144 & -57.58 & -56.10 & -58.82 & 1.4382 \\
\hline sp1 & 2156 & 8 & -9.46 & -9.41 & -9.52 & 0.0020 & -62.85 & -62.50 & -63.20 & 0.0916 \\
\hline su10 & 2500 & 1 & -9.78 & -9.78 & -9.78 & & -65.30 & & & \\
\hline
\end{tabular}

Labels refer to Fig. 1, rain water and snow or snowmelt analyses are not included. Averaged values in springs are not corrected for discharge. Isotope concentrations are given in $\delta$ units calculated with respect to VSMOW (Vienna Standard Mean Ocean Water) expressed in \%o. 
March 2005. However, temporal variations of stable isotopes in these springs reflect rainfall events with different isotopic signatures which are not eliminated by dispersion and hence indicate comparatively short residence times.

Since the isotopic composition of springs represents the average altitude of their recharge area, the mean elevation of the recharge area can be calculated using the isotopic composition of precipitation at different altitudes. Recharge altitudes could not be derived from direct measurements because no reliable data on rainfall isotopic composition could be obtained during the sampling campaigns as mentioned above. Since the formation of vapour in the atmosphere and the formation of rain shows similar altitude dependencies (Clark and Fritz, 1999), recharge altitudes were derived by combining gradients of altitude versus $\delta^{18} \mathrm{O}$ from isotopic data of atmospheric vapour obtained by Raya Garrido (2003) with a mean average winter value of precipitation. Raya Garrido (2003) divided the gradients into a lower and an upper altitude gradient separated by the atmospheric boundary layer (ABL). The atmospheric boundary layer is the part of the troposphere that is directly influenced by convective circulation originated by the shape and different heat capacities of the earth surface (Stull, 1988). It is often turbulent and is capped by a statically stable layer of air or temperature inversion. The ABL depth (i.e., the inversion height) is variable in time and space, ranging from tens of metres in strongly statically stable situations, to several kilometres in convective conditions over deserts. On the basis of

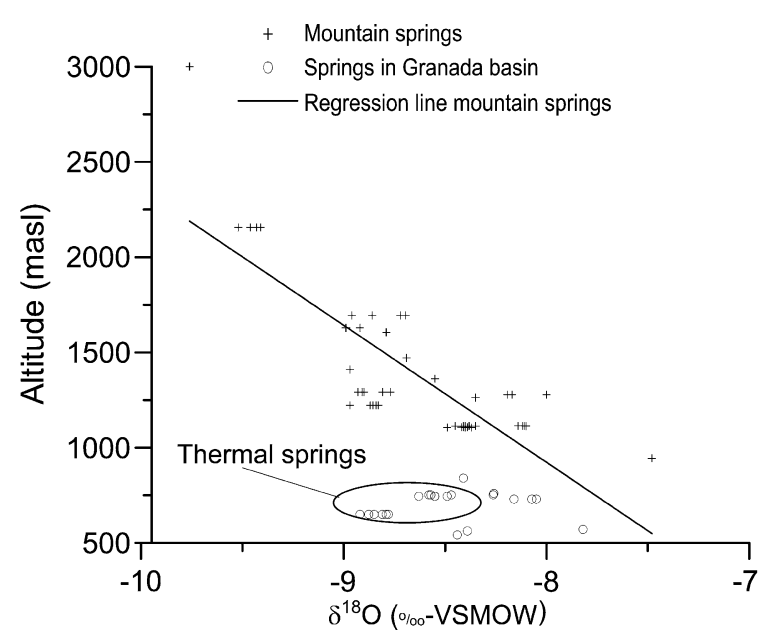

Fig. 11. $\delta^{18} \mathrm{O}$ values of analysed spring samples plotted versus altitude. isotope measurements of atmospheric vapour Raya Garrido (2003) estimated an ABL altitude of 2200 masl and altitude versus $\delta^{18} \mathrm{O}$ gradients of -0.2 $\% o / 100 \mathrm{~m}$ for $670-2200$ masl and $-1.3 \% / 100 \mathrm{~m}$ above 2200 masl for the northwestern slope of the Sierra Nevada, which is located east and SE of Granada basin. This is in agreement with $\delta^{18} \mathrm{O}$ gradients between -0.19 and $-0.31 \% / 100 \mathrm{~m}$ of different isotope studies of precipitation for these altitudes compiled by Craig (1961). Longinelli and Selmo (2003) reported a gradient of $-0.2 \% / 100 \mathrm{~m}$ for Italy. Values of $\delta^{18} \mathrm{O}$-altitude gradients compiled by Clark and Fritz (1999) ranged between $-0.2 \% / 100 \mathrm{~m}$ and $-0.3 \% / 100 \mathrm{~m}$.

On these assumptions, recharge elevations for Sierra Nevada springs were estimated by extrapolating these gradients from a starting point. This starting point is the mean weighted winter value of $\delta^{18} \mathrm{O}=-6.9 \%$ measured by Raya Garrido (2003) at the rainwater sampling station Generalife in Granada (845 masl) (Fig. 12). Starting from this reference point the $\delta^{18} \mathrm{O}$ gradients lead to the following equations for the corresponding altitudes

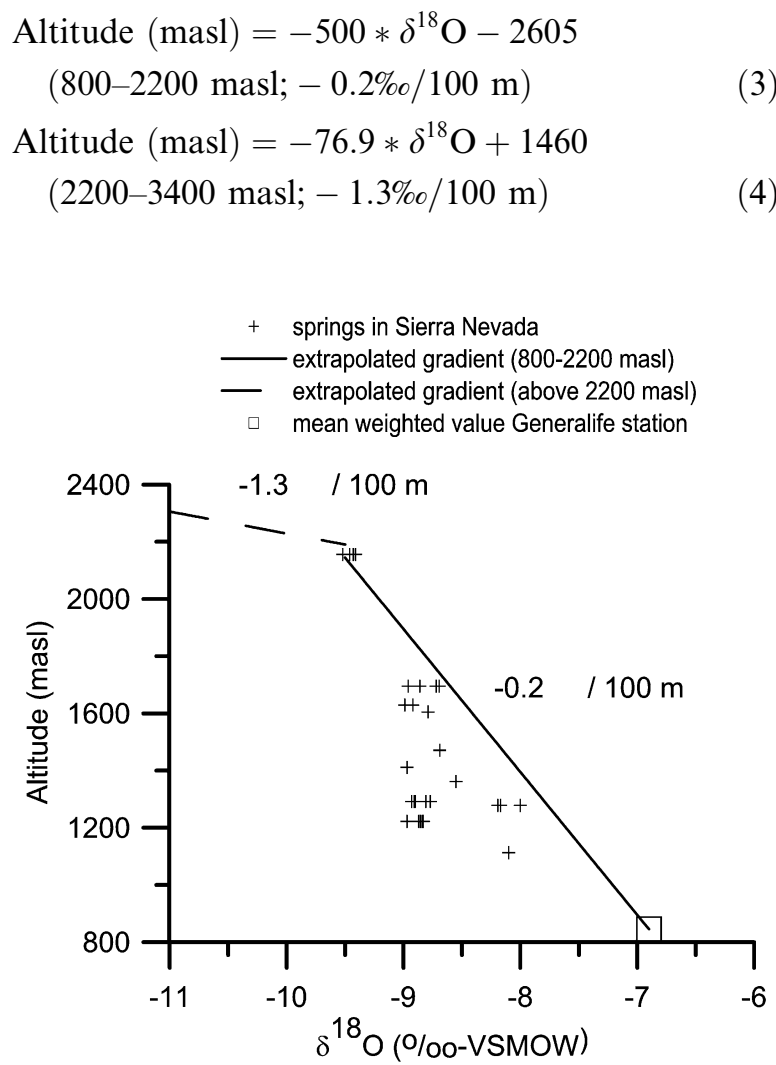

Fig. 12. $\delta^{18} \mathrm{O}$ values of Sierra Nevada springs versus altitude and calculated $\delta^{18} \mathrm{O}$ gradients derived by Garrido (2003) used for the calculation of recharge elevations. 
Irrespective of their real spring elevations, the computation of recharge isotope elevations yielded altitudes between 1700 and 2000 masl for most of the Sierra Nevada springs (Fig. 13). This altitude corresponds generally to the lithologic boundary between micaschists and carbonate rocks. Recharge at these altitudes results predominantly from snow melting. No seasonal difference was observed between samples taken at the beginning and at the end of the hydrological period of recharge, which may be due to the fact that recharge is limited to the winter and spring. The fact that these springs discharge water throughout the year indicates longer residence times which eliminate seasonal effects and the temporal change of isotope composition of snowmelt. The samples of snowmelt analysed in this study were taken at altitudes between 2750 and 3473 masl and therefore show more depleted signatures of heavy isotopes than analysed spring samples shown in Fig. 9.

The springs of the Sierra Nevada, whose altitudes range between 1200 and 2160 masl, reflect an altitude effect with an isotope gradient around -0.14 $\% / 100 \mathrm{~m}$ (Fig. 11). The deviation of this gradient from isotope gradients obtained from precipitation $(\sim-0.2 \%$ o/ $100 \mathrm{~m})$ is due to the fact that spring altitudes do not correspond necessarily to recharge altitudes. This only applies for springs with very small catchment areas and is not the case in the present study area. In general and especially with regard

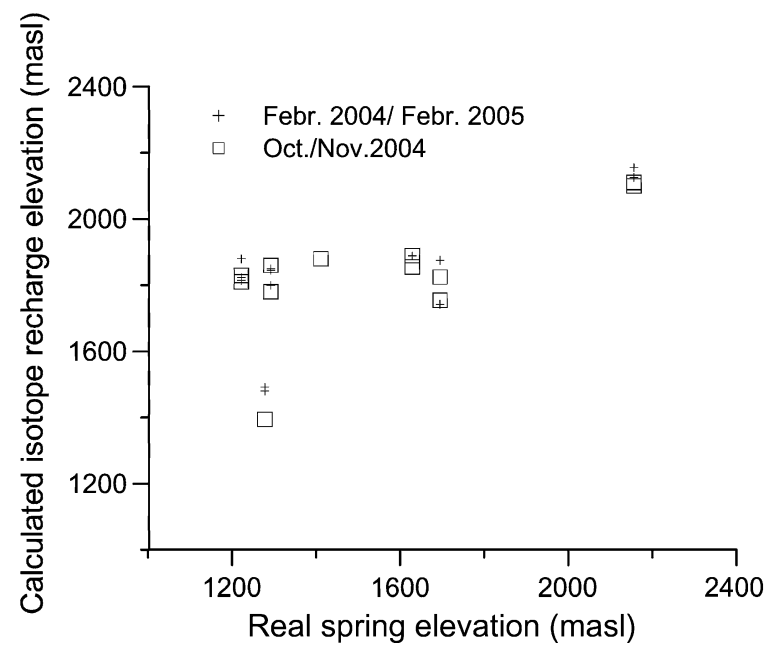

Fig. 13. Real spring elevation versus calculated isotope recharge elevation of mountain springs from the February and March $\delta^{18} \mathrm{O}$ values. to the thermal springs, $\delta^{18} \mathrm{O}$ values of springs in the Granada basin are comparatively light in relation to their altitude, indicating that most of the recharge of these springs occurs in higher areas of the adjacent mountains. This is in accordance with the similarity of hydrogeochemical data between samples taken at springs in carbonate host rocks in the mountain area and samples taken in the eastern part of the Vega de Granada aquifer as discussed above.

Isotopic enrichment of the surface water system due to the altitude effect can be observed along the sampling stations of Genil River (Fig. 14). The uppermost sample (su1, 1179 masl) is characterised by light isotope composition with strong seasonal variations which is supposed to be the effect of isotopic compositions of snowmelt. Downstream of the Canales reservoir (su3), which dams the Genil River, the seasonal variations observed upstream at sul are eliminated because the reservoir acts as a mixing pond. Following the course of the Genil further downstream the next site is situated in the Mio-/Pliocene basin fill (su4). This site is clearly influenced by the Quentar reservoir (su9, 1010 masl), which discharges into the Genil River here, and shows a heavy isotopic composition in relation to its altitude. This reflects the lower altitudes of the catchment area of this reservoir. The lowermost sampling station of the Genil River (su13, 560 masl) is located in the

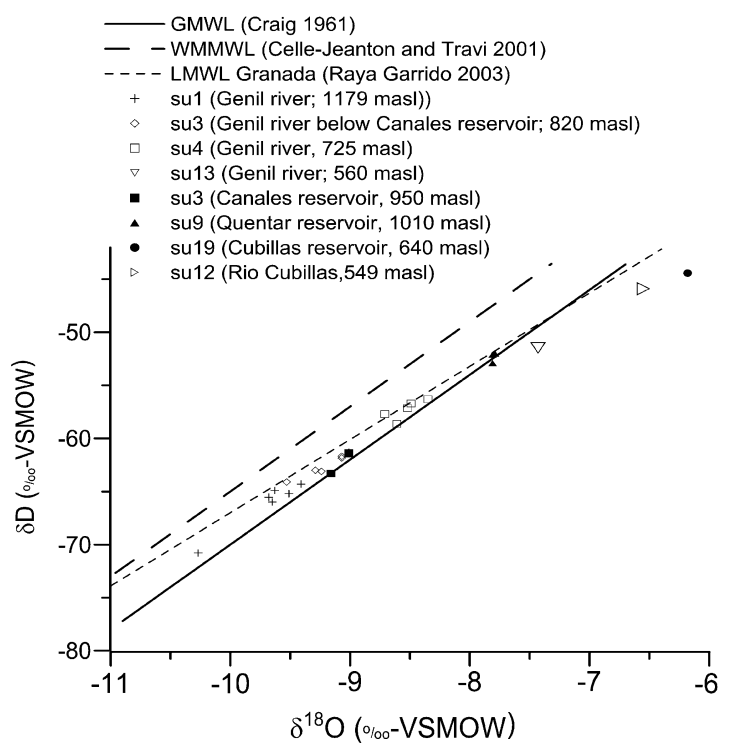

Fig. 14. $\delta D$ versus $\delta^{18} \mathrm{O}$ data of surface water collected between February 2004 and March 2005. Abbreviations in the figure key refer to sampling locations illustrated in Fig. 1. 


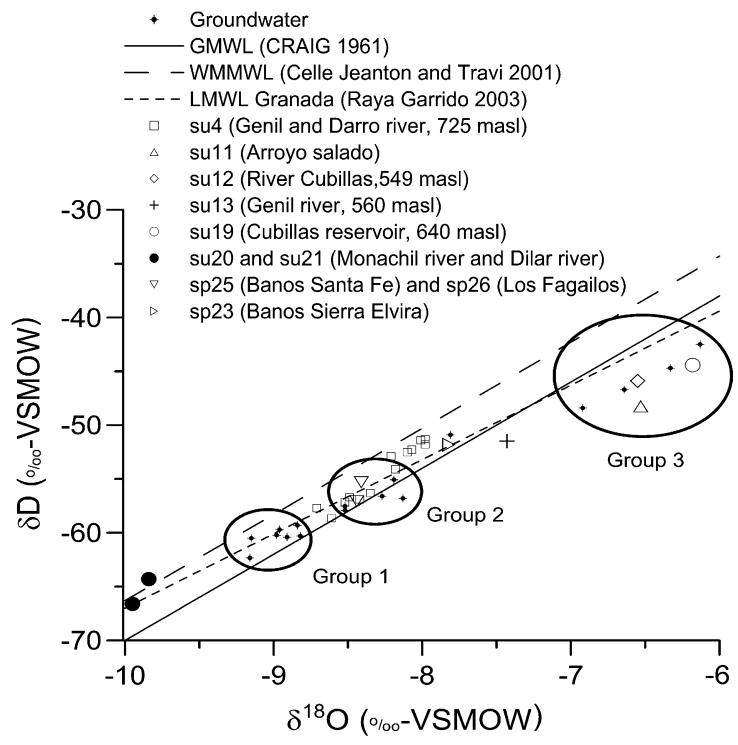

Fig. 15. $\delta D$ values of analysed groundwater and selected surface water samples plotted versus $\delta^{18} \mathrm{O}$. Abbreviation refers to sampling locations in Fig. 1.

western part of the Granada basin. This sample is strongly influenced by the Cubillas reservoir (su19, 640 masl), which discharges into the Genil River via the Cubillas River (su12). The Cubillas reservoir shows significant evaporative isotope enrichment as a consequence of its shallow depth and its low altitude. This is also reflected in the Genil River sampling station su13, which plots on a mixing line between the Cubillas reservoir (su19) and the next Genil River sample located upstream (su4).

Three different groups of groundwater samples were distinguished according to their isotopic compositions (Figs. 15 and 16). The first group of wells (group 1) shows a lighter isotopic composition than the samples of the Genil River, indicating that groundwater of the southeastern part of the aquifer is recharged partly by the Monachil River and the Dilar River which are both characterised by very light isotopic signatures. Nonetheless, a considerable recharge of subsurface flow has to be assumed here because group 1 is enriched in heavy isotopes in comparison with the Dilar and Monachil Rivers. This recharge by subsurface runoff is likely to occur at the southeastern boundary of the aquifer where it cuts across the more permeable carbonate rocks. This has not been verified by measurements so far owing to the lack of piezometers in carbonate rocks.

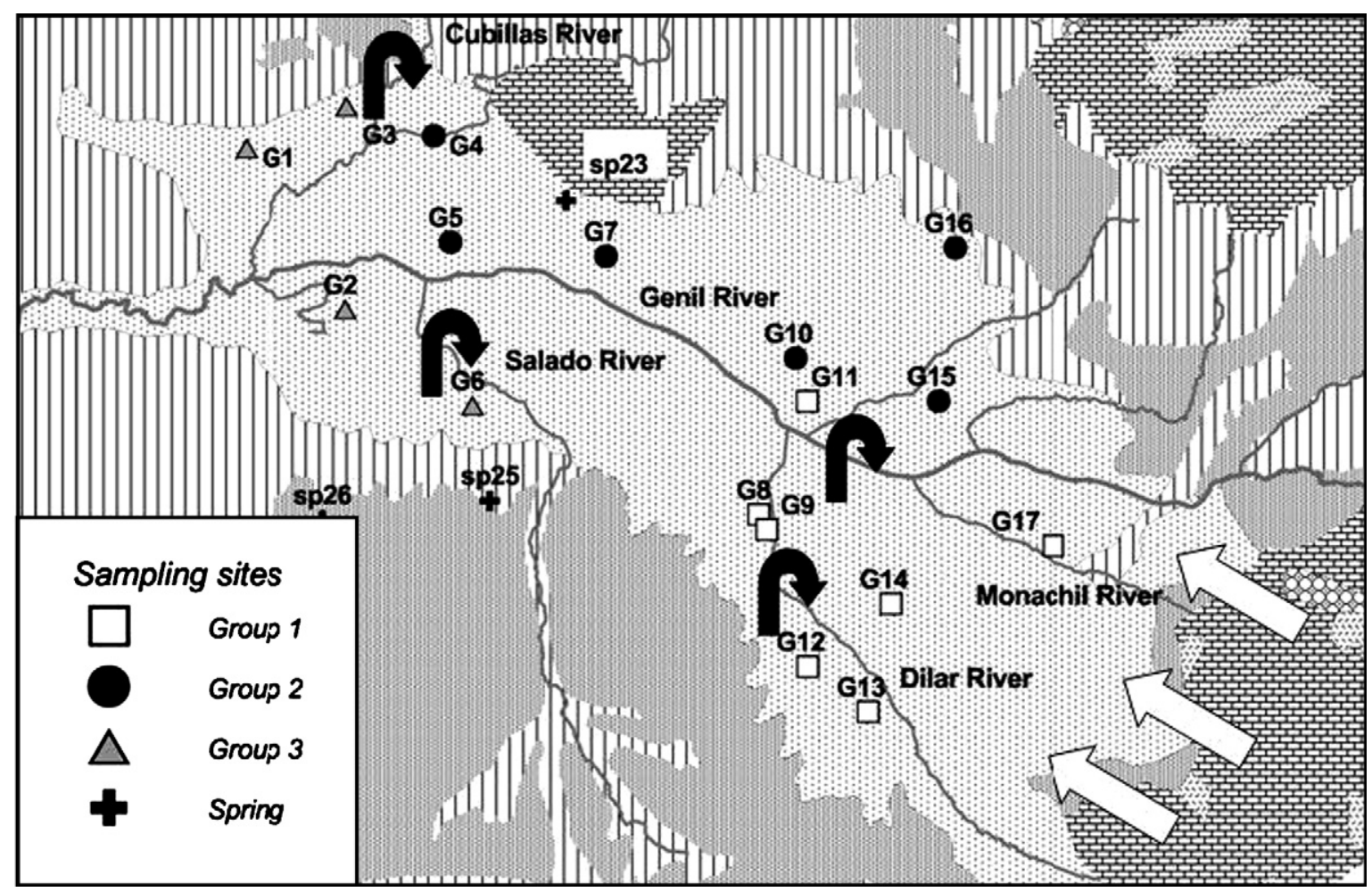

Fig. 16. Locations and isotopic composition of groundwater sampling sites. Label plots refer to groups defined in Fig. 15. For geology refer to Fig. 1. Black arrows indicate river infiltration and white arrows stand for subsurface flow. 
Recharge of surface runoff by the small creek in the southeastern part of the aquifer was assumed to be only of minor importance considering its small discharge.

The second group of groundwater samples are all located in the northern and central part of the aquifer; they plot close to the Genil River samples and indicate an important recharge by infiltration of the Genil River.

The samples of group 3 are located in the western part of the aquifer and are characterised by an evaporative enrichment of heavy isotopes. The samples plot close to the tributaries Rio Cubillas (su12) and Arroyo Salado indicating a predominant groundwater recharge by these surface water systems. Adjacent spring water samples ( $\mathrm{sp} 25$, sp26) close to Arroyo Salado show a distinct isotopic signature. Since these springs drain the Neogene sediments and represent its groundwater composition, groundwater recharge of the Quaternary aquifer by subsurface flow is considered to be of minor importance. Thus, aquifer recharge by subsurface flow discharged by the adjacent Neogene basin sediments could not be detected. This is in agreement with the low hydraulic conductivities of these sediments which consist mainly of clays and silts.

\section{Conclusions}

The following conclusions can be drawn from the results of the present study.

- Rising mineralisation due to calcite dissolution is clearly associated with the temperature and the partial pressure of $\mathrm{CO}_{2}$ in the recharge area.

- Rising $\mathrm{Mg} / \mathrm{Ca}$ ratios with greater distance to the source area indicate kinetically controlled dissolution of dolomite after equilibrium controlled dissolution of calcite.

- The recharge altitudes of most of the springs located in the Sierra Nevada are about 1700 masl which leads to the conclusion that recharge of the entire watershed is predominantly due to winter rain and melting snow.

- Isotopic characteristics of springs and thermal springs located in the Granada basin indicate recharge areas at higher altitudes.

- The temporal isotopic pattern of the Genil River along its flow path reflects the elimination of seasonal effects due to the Canales reservoir. The discharge from other reservoirs subjected to evaporation loss shows a strong influence on the isotopic composition of the Genil river.

- The recharge of the aquifer by the main rivers Genil, Dilar and Cubillas is clearly reflected by the isotopic composition of the groundwater and allows a spatial assignment of aquifer areas to their recharge sources. Groundwater recharge of the Quaternary aquifer by lateral subsurface runoff was detected and is limited to groundwater discharge of the adjacent karstic aquifer of the Alpujarride Complex.

- Important evaporative loss of water due to irrigation could not be confirmed by the isotope pattern of the groundwater. Isotopic enrichment in the western part of the basin is clearly associated with tributaries of isotopically enriched surface water discharged by the Cubillas reservoir, which is subject to intensive evaporation.

\section{Acknowledgements}

The authors are grateful to Luis O'Dogherty and Mari Carmen Hidalgo for providing most of the snow samples. The study was conducted within the cooperation between Freie Universität Berlin, Universidad de Granada, Alfred Wegener Institut (AWI) Potsdam and Instituto Geológico Minero de España (IGME). The authors thank Prof. Hans Hubberten for scientific support during isotope sampling and analyses, IGME for financial and logistical support of this research and AWI for analyses of stable isotopes.

\section{References}

Barbieri, M., Boschetti, T., Pettita, M., Tallini, M., 2005. Stable isotope $(2 \mathrm{H}, 18 \mathrm{O}$ and $87 \mathrm{Sr} / 86 \mathrm{Sr})$ and hydrochemistry monitoring for groundwater hydrodynamics analysis in a karst aquifer (Gran Sasso, Central Italy). Appl. Geochem. 20, 2063-2081.

Castillo, A., 2000. Parque Nacional de Sierra Nevada. Clima e Hidrología. Instituto del Agua (Universidad de Granada), Granada.

Castillo, A., 2005. El acúfero de la Vega de Granada. Ayer y hoy (1966-2004). In: López Geta (Ed.), Agua, Minería y Medio Ambiente, Libro Homenaje al Profesor Rafael Fernández Rubio. IGME, pp. 161-172.

Castillo, A., Sanchez Diáz, L., 2005. Problemática de la calidad de las aguas de la Vega de Granada para el riego del tabaco, Simposio del Agua en Andalucía. Publicaciones del IGME: serie Hidrogeología y aguas subterráneas, no. 14, pp. 669 678. 
Celle-Jeanton, H., Travi, Y., 2001. Isotopic typology of the precipitation in the Western Mediterranean region at three different scales. Geophys. Res. Lett. 28, 1215-1218.

Clark, I., Fritz, P., 1999. Environmental Isotopes in Hydrogeology. Lewis Publishers, New York.

Cook, P.G., Herczeg, A.L., 1999. Environmental Tracers in Subsurface Hydrology. Kluwer Academic Press, Boston, MA.

Craig, H., 1961. Isotopic variations in meteoric waters. Science 133, 1702-1703.

Cruz-San Julian, J., Araguas, L., Rozanski, K., Benavente, J., Cardenal, J., Hidalgo, M.C., García Lopez, S., Martinez Garrido, J.C., Moral, F., Olias, M., 1992. Sources of precipitation over South-Eastern Spain and groundwater recharge. An isotopic study. Tellus B 44, 226-236.

DEM, 1999. Mapa digital de Andalucía. Conserjería de obras públicas y transportes, Sevilla.

Garrido, J., 2003. Composición isotópica del vapor de agua atmosférico en el sureste de la península ibérica. Doctoral Thesis, Granada.

IAEA/WMO, 2001. Global Network for Isotopes in Precipitation. The GNIP Database. Accessible at http://isohis.iaea.org.

IGME, 1988. Atlas Hidrogeológico de la Provincia de Granada. IGME.

Long, A.J., Putnam, L.D., 2004. Linear model describing three components of flow in karst aquifers using ${ }^{18} \mathrm{O}$ data. $\mathrm{J}$. Hydrol. 296, 254-270.

Longinelli, A., Selmo, E., 2003. Isotopic composition of precipitation in Italy: a first overall map. J. Hydrol. 270, 75-88.

Marfia, A.M., Krishnamurthy, R.V., Atekwana, E.A., Panton, W.F., 2003. Isotopic and geochemical evolution of ground and surface waters in a karst dominated geological setting: a case study from Belize, Central America. Appl. Geochem. 19 937-946.

Meyer, H., 2000. Isotope studies of hydrogen and oxygen in ground ice - experiences with the equilibration technique. Isotopes Environ. Health Studies 36, 133-149.

Parkhurst, D.L., 1995, User's guide to PHREEQC - A computer program for speciation, reaction-path, advective-transport, and inverse geochemical calculations. US Geol. Surv. WaterResour. Invest. Rep. 95-4227.

Parkhurst, D.L., Appelo, C.A.J., 1999. User's guide to PHREEQC (Version 2) - A computer program for speciation, batchreaction, one dimensional transport, and inverse geochemical calculations. US Geol. Surv. Water-Resour. Invest. Rep. 994259 .

Plata Bedmar, A., Greciano González, R. (Eds), 2000. Hidrología isotópica y hidroquímica del acuifero cuaternario de la vega de Granada. Ingenería Civíl, p. 120.

Raya Garrido, J., 2003. Composición isotópica del vapor de agua atmosphérico en el sureste de la Peninsula Ibérica, Universidad de Granada, Granada.

Sidle, W.C., 1998. Environmental isotopes for resolution of hydrology problems. Environ. Monitor. Assess. 52, 389-410.

Stull, R.B., 1988. An Introduction into Boundary Layer Meteorology. Kluwer Academic, Dordrecht.

Stumm, W., Morgan, J.J., 1996. Aquatic Chemistry. Wiley Interscience, New York.

Vandenschrick, G., van Wesemael, B., Frot, E., Pulido-Bosch, A., Molina, L., Stiévenard, M., Souchez, R., 2002. Using stable isotope analysis to characterise the regional hydrology of the Sierra de Gador, south east Spain. J. Hydrol. 265, 4355 . 